\title{
Microbial biofilms and some aspects of anti-inflammatory drug use
}

\author{
T. M. Rumynska ${ }^{1}$, A. R. Hural ${ }^{1}$, Y. T. Konechnyi ${ }^{1}$, R. B. Vynnytska ${ }^{2}$, A. V. Lozynskyi ${ }^{1}$, \\ Y. T. Salyha ${ }^{3}$, O. P. Korniychuk ${ }^{1}$, R. B. Lesyk ${ }^{1,4}$ \\ ${ }^{1}$ Danylo Halytsky Lviv National Medical University \\ 69, Pekarska Str., Lviv, Ukraine, 79010 \\ ${ }^{2}$ Ivano-Frankivsk National Medical University \\ 2, Halytska Str., Ivano-Frankivsk, Ukraine, 76018 \\ ${ }^{3}$ Institute of Animal Biology, NAAS of Ukraine \\ 38, Stusa Str., Lviv, Ukraine, 79034 \\ ${ }^{4}$ University of Information Technology and Management in Rzeszow \\ 2, Sucharskiego Str., Rzeszow, Poland, 35-225 \\ dr_r_lesyk@org.lviv.net,roman.lesyk@gmail.com (Roman Lesyk)
}

The review presents literature data on the effect of nonsteroidal anti-inflammatory drugs (NSAIDs) on the formation of bacterial biofilms. The role of biofilm structures as a factor of virulence of microorganisms is shown, and the protective reactions of a macroorganism in infectious processes caused by bacteria — producers of biofilms are characterized. The article also provides the examples of methods for studying biofilm formation and strategies for managing this process. The prospects of further study of the complex interaction between bacterial pathogens in biofilms are shown, which may help to develop further therapeutic strategies against the biofilm-dependent infections.

Key w o r d s: NSAIDs, microbiota, dysbiosis, prostanoids, cyclooxygenase, biofilms

\section{Introduction}

Modern medicine uses a considerable arsenal of drugs of etiotropic, pathogenetic, or symptomatic action to treat infectious and inflammatory processes. Diseases caused by microorganisms in the form of biofilms are complex or not at all amenable to treatment since mi- croorganisms in the composition of biofilms acquire several environmental and physiological advantages, which consist in the formation of a physical barrier for the specific and nonspecific protection of bacteria against the effects of stress factors, including antibiotics and

(C) 2021 T. M. Rumynska et al.; Published by the Institute of Molecular Biology and Genetics, NAS of Ukraine on behalf of Biopolymers and Cell. This is an Open Access article distributed under the terms of the Creative Commons Attribution License (http://creativecommons.org/licenses/by/4.0/), which permits unrestricted reuse, distribution, and reproduction in any medium, provided the original work is properly cited 
disinfectants. The process of recognition of microorganisms by the host immune system is also disrupted. The strategy of the biofilm is to ensure the survival of the community of microorganisms, protection, and transmission of their genetic information. When interacting with a macroorganism, biofilms enhance the inflammatory process by expressing virulence factors, counteracting protective reactions, which determines the generalization of the process with the participation of the dispersed phase.

In recent years, special attention has been paid to the issues related to the film formation on catheters, implants, endotracheal tubes, etc., in the conditions of artificial ventilation. The catheter-associated infections challenge the treatment with antibiotics, and there is a need to replace catheters because of biofilms on their surfaces. However, the biofilm structures formed by representatives of the normosymbiont microbiota in natural ecosystems of humans or animals, being in eubiotic relations with the macroorganism, have a powerful protective function against the invasion of pathogens as a factor of colonization resistance. The preservation of integrity contributes to the implementation of many useful functions of the normal flora.

The biofilm formation by probiotic bacteria, such as Lactobacillus spp., is valuable because it can promote colonization and long-term stability in the host mucosa, avoiding colonization by pathogenic bacteria [1]. It has been proven that lactic acid bacteria are able to induce the death of staphylococci in the biofilm form without converting them to planktonic ones. The biofilm form of lactobacilli provides stability in the population and performs immunocorrective functions [2].

\section{Biofilm structures as a factor of viru- lence of microorganisms}

Detection of the ability of microorganisms to the supracellular organization - the formation of a biofilm - is one of the most important areas of research in modern microbiology. The term "biofilm" was proposed by J. Costerone in 1978 to denote microbial agglomerations that grow on a dense surface $[3,4]$.

According to this concept, the populations of microorganisms exist in two main forms planktonic, when life processes occur in the liquid phase, and in biofilms - a special form of extracellular organization, which arises at the boundary of two phases of the environment - liquid and dense. Such forms of existence of microbial populations are known in both natural conditions and organisms of animals or humans [5].

Certain characteristics distinguish the biofilm: stage of development, morphology, and physiological properties of bacteria that determine the interaction with the environment and macroorganisms [6]. The biofilm is characterized by a three-dimensional structure that includes cellular elements and an extracellular matrix (glycocalyx). Extracellular polymeric substances (EPSs) play an important role in the formation of biofilms. The biofilm architecture provides free access of metabolites and signaling molecules from the environment to the cells due to the presence of microchannels formed by glycocalyx molecules [7]. As a part of the biofilm, the cells are characterized by a certain specialization in the synthesis of components of the extracellular matrix, which is the organic basis of the biofilm, as well as genotypic and phenotypic manifestations of functional activity [8]. 
With the development of the infectious process, the bacterial biofilms suppress the body's protective reactions. In particular, due to the ability of bacteria in biofilms to respond to signaling molecules of the microorganism, the phagocytosis is suppressed $[9,10]$, the cascade of reactions of activation of the complement system and other protective reactions of the organism - killer effects, opsonization of microorganisms by antibodies, other cellular immune reactions are blocked. There is an activation of genes that determine the synthesis of toxins, enzymes, and other virulence factors [11]. Additionally, the formation of biofilms depends on the course of energy processes in the body, particularly on the level of cAMP and ATP [12, 13] and other biochemical reactions.

As indicated, the infectious properties of microorganisms, in particular bacteria, depend on reaching a certain quantitative threshold "quorum sensing", because, with a small amount of pathogen, the protective systems of the macroorganism can recognize and neutralize the virulence factors and block the development of infectious processes, which fails at above-threshold concentrations of microbial cell biofilms. Such diseases are called "quorum sensing-dependent infections" [14].

An essential feature of biofilms is the ability to resist antibiotics and other antimicrobials [15]. Such resistance develops with the participation of various mechanisms that depend on genotype and phenotypic characteristics. These include the changes in the structure of the cell wall, blocking the penetration of the antibiotic into the cell through the barriers of the capsule or glycocalyx, the production of enzymes that destroy antibiotics, changes in the metabolic processes sensitive to the action of antibiotics. Separate mechanisms provide rapid removal of the antibiotic from the cell (efflux). The biofilm architecture provides the formation of surface cellular structures capable of resisting antibiotics so that the deep components of the cell are not exposed to the antibiotic [16].

Under the influence of unfavorable factors, individual cells of the biofilm can acquire the ability for persistence — stability and longterm survival under the action of this factor (persister cells). The persister cells determine the possibility of recurrence after the treatment of infectious diseases with antibiotics [17, 18]. The ability to form a film has been identified and studied in many pathogenic and opportunistic bacteria and unicellular fungi species. Hospital strains of $S$. aureus were characterized by the ability to form a film and the resistance to antibiotics [19, 20]. In many species of the Enterobacteriaceae family, biofilmforming variants are multidrug-resistant [21]. In particular, such properties were found in the antigenic variant of $E$. coli $\mathrm{O} 26$, pathogenic for children and young farm animals [22].

Manifestations of the pathogenic action of $P$. aeruginosa are associated with the ability to form biofilms that correlate with toxin formation and antibiotic resistance [23].

The ability to form films has been found in campylobacteria, particularly $C$. jejuni, as a major species that causes intestinal infections through food (poultry meat) [24]. Film formation is one of the essential factors in the pathogenicity of Candida fungi, and such strains were characterized by resistance to chlorhexidine [25]. The biofilms formed on the mucous membranes of open cavities of the human 
body may contain several species of microorganisms - gram-positive and gram-negative bacteria and fungi, including the genus Candida [26].

\section{Protective reactions of a macroorgan- ism at infectious processes caused by bacteria - producers of biofilms}

As part of the biofilm, bacteria can avoid the recognition by the immune system. The first stages of such recognition are provided by the interaction of pattern-associated molecular structures - patterns (PAMP) with TLR receptors of the cells [27]. Such recognition activates the cascade of immune-mediated inflammatory reactions - synthesis of interleukins, acute phase proteins, prostaglandins. Analyzing the study results of the body's protective reactions against bacteria - producers of biofilms, the author of the review questions their effectiveness, pointing out that "mission is impossible" [28]. However, this review provides the data on the importance of neutrophils in protective reactions in film-mediated infections. The conclusion is that protection against such infections is possible in the early stages of biofilm formation. One of such protection mechanisms is the formation of superantigens - a complex of bacterial structures directly recognized by $\mathrm{T}$ - lymphocytes and form the cell immune defense. As a result, the formation of the biofilm is inhibited [29].

Therefore, the ability of microorganisms to organize biofilm structures should be attributed to the most important properties of unicellular organisms, which determine their pathogenecity and ability to resist the influence of external factors, protective reactions of the macroorganism, the action of antimicrobial agents, ensuring their survival (persistence) in adverse conditions.

Based on the study of genetic factors and biochemical processes in the formation of biofilms, the strategies to control film formation, as a critical element in the pathogenesis of infections, are formed [30].

\section{Methods of studying biofilm formation}

To study biofilms, in vitro and in vivo models could be used. The biofilm research technologies are presented in the review [31], with attention to two-component media. The fact of biofilm formation can be detected by the washing-resistant changes in the surface and the transparency of the dense phase. Conventional methods of microscopy allow identifying the initial stages of formation of biofilms - the formation of microcolonies. Scanning electron microscopy [32] is used to study the biofilm structure in more detail. Scanning fluorescence microscopy methods are used to study the biofilm in live form, especially in real-time flow chambers [33]. To study biochemical processes in biofilms, flowing liquid microcameras are used, making it possible to detect metabolites and the influence of environmental factors in dynamics [34].

The methods for quantifying the processes of biofilm formation are given in the review [35]. The standard method for detecting biofilm is the method of polystyrene plates with crystal violet staining. One of the following techniques for quantitative study of total metabolic activity of the biofilm is XTT ((2,3-bis(2-methoxy-4-nitro-5-sulfophenyl))5-[(phenylamino)carbonyl]-2H-tetrazolium hydroxide reduction)) which is mainly used for the quantification of Candida biofilm [35]. 
Congo red and luminescent dyes are also used. More complicated methods include bioluminescent analysis, scanning electron or laser microscopy, infrared spectroscopy; however, they require complex and expensive equipment.

In vitro modeling makes it possible to study the processes of film formation that depend on the properties of the microbial population. In vivo methods have been proposed to study the interaction of biofilms with a macroorganism [36]. The most common models are catheters placed under the animal's skin, whereby the biofilm is formed in the catheter before its introduction. Another technique involves the introduction of bacteria capable of film formation through catheters [37].

For a similar purpose, the subcutaneous fixation of porous balls, inserted into catheters with bacteria, is used [38].

Mice, rats, guinea pigs, and in some cases, piglets are used as experimental animals. A method of research using Drosophila is also proposed. Endocarditis and wound infection were simulated using surgery [39].

\section{Strategies for managing biofilm for- mation processes}

The formation and development of the biofilm are influenced by numerous factors, including bacterial strain characteristics, surface properties, and environmental parameters such as $\mathrm{pH}$, nutrient concentration, and temperature [40].

The results of biofilm research indicate the need to develop the strategies for managing film formation processes in a set of antimicrobial treatment measures [41]. First of all, these strategies aim to inhibit and destroy biofilms by drugs with different mechanisms of action.
It was found that the formation of biofilms is carried out with the participation of signaling molecules-oligopeptides in gram-positive bacteria and $\mathrm{N}$-acylhomoserine lactones (AHL) in gram-negative bacteria $[42,43]$. The use of inhibitors will allow inhibition of film formation.

As a part of biofilms, bacteria can resist "starvation stress" due to the synthesis of alarmons - guanosine derivatives (ppGpp). This process is inhibited by a peptide (1018-peptide), which blocks the film formation. Degradation of the biofilm EPSs by the enzymes such as DNase or glycoside hydrolase also causes the biofilm degradation, and proteases destroy protein components. A clinical effect in treating infections caused by biofilmproducing bacteria with the drugs such as polymyxins and gramicidins, which destroyed lipopolysaccharide components of the cell wall of gram-negative bacteria, has been reported [44]. Additionally, degradation of biofilms can occur under the action of drugs with antimicrobial activity produced by probiotic microorganisms (subtilin, nisin), which destroy the cytoplasmic membrane $[45,46]$.

Inhibition of film formation is also observed with the use of drugs that block cell division (silver, antibiotics impact on cell wall/protein synthesis or DNA gyrase) [47, 48]. Moreover, one of the key stages - adhesion - is blocked by some peptides (indolicidin-antimicrobial peptide isolated from cow's blood neutrophils). Some drugs are used, for example, to prevent the formation of biofilms on contact lenses [49].

Some extracellular polysaccharides inhibit the formation of biofilms and lead to the destruction of pre-formed biofilms [50]. 
Therefore, the drugs that block the formation of cyclic diguanosine monophosphate (diGMP), which is involved in the dispersion of the biofilm, which, in turn, contribute to the generalization of the infectious process, have a potential therapeutic effect [51].

The strategies to overcome the adverse effects of biofilm are aimed at finding and using drugs that block the film formation and the development of the inflammatory process in the early stages. Such substances include NSAIDs-cyclooxygenase inhibitors (COX), which inhibit the reproduction of bacteria capable of film formation. The action of NSAIDs is mediated by inhibition of the synthesis of pro-inflammatory prostaglandins. In combined biofilms involving Candida fungi and bacteria, bacterial growth is stimulated by the synthesis of prostaglandin PGE2 by fungi, and NSAIDs inhibit this effect. The phenomenon of film formation requires further study, particularly in the modeling of tools and drugs to overcome their adverse effects in the macroorganism.

\section{Influence of NSAIDs on biofilm for- mation processes}

NSAIDs are among the most widely used drugs, and their use for therapeutic purposes is becoming widespread. According to the WHO, more than $20 \%$ of the population of our country regularly takes NSAIDs. In 70$60 \%$ of patients, their high efficiency is not in doubt. The main pharmacological effects of NSAIDs are anti-inflammatory, analgesic, antipyretic action. However, the primary mechanisms of their activity are not fully disclosed. NSAIDs' central molecular mechanisms of action include their cyclooxygenase (COX) inhibitory activity [52]. In turn, COXs are involved in synthesizing prostaglandins, a group of molecules produced by many body cells, and have a broad spectrum of action.

Pro-inflammatory prostaglandins (PG2) are involved in the development of inflammatory processes of microbial genesis. The development of the inflammatory process under the influence of virulence factors of microorganisms is mediated through a system of pro-inflammatory cytokines - interleukins and prostaglandins. The influence of pro-inflammatory interleukins in the development of urogenital infections caused by $E$. coli has been studied in detail [53, 54]. Yimer et al. [55] emphasize the role of NSAIDs as potential sources of new antibacterial agents, with which the previous studies and randomized controlled trials have been conducted. The review also considers the possible antibacterial mechanism of action and NSAIDs' likely effectiveness in combination with traditional antibacterial drugs [55]. In studying the mechanism of action of NSAIDs on bacteria, it was found that some NSAIDs are the substrates, to which the pumping mechanisms at efflux effects among gram-negative bacteria are directed. Aspirin is likely to cause efflux-mediated resistance to fluoroquinolones in some strains of E. coli [56].

The results of studying the effect of NSAIDs on the activity of bacterial biofilms are presented in work [57]. Standard strains of S. aureus (ATCC 6538), K. pneumoniae (ATCC 10031), Ps. aeruginosa (ATCC 10145), and the clinical strain Proteus mirabilis were investigated. The ability to form a film was controlled by the method of plates when stained with crystal violet. Minimum antimicrobial concentration of the antibiotic (MIC) was determined by the method of diffusion from agar 
wells. The effects of NSAIDs (ketobrufen, ibuprofen, diclofenac sodium) and $\mathrm{N}$-acetylcysteine, individually and in combination, were studied. Ibuprofen showed the highest antibacterial effect and the lowest MIC against $S$. aureus, Ps. aeruginosa, and Proteus mirabilis, whereas diclofenac sodium showed the highest activity against $K$. pneumoniae.

In the study of synergism between the biofilm forms of bacteria ( $S$. aureus, E.coil, P. aeruginosa) and Candida fungi, it was found that this effect depends on the production of pro-inflammatory prostaglandin PGE2 [58], which causes a pronounced influence on the development of inflammatory process and protective reactions of the body, inhibits natural killers, a function of granulocytes, alveolar macrophages and inhibits phagocytosis [59]. The complex relationship between the components of biofilms involving Candida fungi is indicated in work [60]. The results of the studies presented in this work indicate the stimulation of $S$. aureus growth in a mixed culture of $S$. aureus and Candida. This effect depended on the production of prostaglandin E2, synthesized by fungi and was removed by indomethacin.

Aspirin (acetylsalicylic acid) is the only known NSAID that, covalently binding to serine, inhibits COX-1 and has an active effect against biofilms in the process of formation as well as against mature forms of $C$. albicans biofilm [61].

The anti-inflammatory drug nimesulide has an antifungal effect on both filamentous and yeast-like fungi. This effect is due to the inhibition of prostaglandin PGE2 synthesis by different species of fungi, including possible anti-biofilm activity [62].
The results of studies of biofilm formation on plastic surfaces have shown that some NSAIDs show good antibacterial activity, a significant effect on inhibiting the adhesion of the studied strains to artificial materials, and a highly destructive effect on mature biofilms. Therefore, the effect of some drugs on the adhesion of $S$. aureus, K. pneumoniae, P. aeruginosa, and Proteus mirabilis on the surface of catheters and their effect on the formed biofilms were studied, antibacterial action was determined [63]. Comparison of the activity of several drugs on the formed biofilms showed that the action of ketoprofen was more potent against the biofilms formed by $S$. aureus, $K$. pneumoniae, and P. mirabilis. However, ibuprofen showed a more pronounced effect on the mature biofilm formed by Pseudomonas aeruginosa.

Thus, many studies have shown that NSAIDs act in synergy with antibiotics. Therefore, the use of NSAIDs may increase the effectiveness of antibiotics, as NSAIDs have a more destructive effect on mature forms of biofilm [57]. Using NSAIDs, as [the] compounds for MIC reduction can adjust the antibiotic therapy, which can positively affect the macroorganisms due to a lower level of development of antibiotic resistance and less toxic effects on the patient's body.

Treatment of infectious and inflammatory processes is often carried out using a combination of antibiotics and anti-inflammatory drugs. The combined effect of NSAIDs with betalactam antibiotics on standard strains of P. aeruginosa (ATCC 10145) and K. pneumoniae (ATCC 10031) is due to the synergy of the drugs. In the study [63], all tested NSAIDs significantly reduced the MIC of an- 
tibiotics against these bacteria and daily inhibitory concentration (FICI). Additionally, antibiotic treatment was more effective, than the use of NSAIDs, in acute uncomplicated lower urinary tract infections with an overall average value of evidence [64].

\section{Conclusions}

NSAIDs can be used successfully against infectious processes caused by microorganisms sensitive to beta-lactam antibiotics. The appointment of specific remedies requires microbiological diagnosis to determine the sensitivity of pathogens to antimicrobial chemotherapeutic drugs. NSAIDs affect microorganisms that form biofilms, but the severity of the effect is different and depends on both the type of NSAIDs and the type and strain of the microorganism - the causative agent of the infectious process. Besides, depending on the type of microorganism, different activity of NSAIDs should be expected against the bacteria whose biofilm formation is at the initial stage and against the bacteria in the form of a mature film structure. Therefore, in some cases it is advisable to employ NSAIDs to adjust the antibiotic dosage in their combined use. Particular attention should be paid to the combination of NSAIDs with fluoroquinolone drugs under the conditions of isolation of the strains resistant to these drugs.

Further study of the interaction processes of fungi-producers of PGE2 in the composition of multicomponent biofilms is needed. Finally, NSAIDs can be successfully used to treat catheter-associated infections, as their activity limits the formation of biofilm structures on polymer surfaces. Further study of the complex interactions of pathogens in the biofilms is required as it may help to develop further therapeutic strategies against the film-dependent infections.

\section{Fundings}

This work was supported by the Ministry of Health of Ukraine [grant number: 0121U100690], the National Research Foundation of Ukraine [grant number: 2020.02/0035].

\section{REFERENCES}

1. Terraf MC, Juarez MS, Nader-Macias ME, Silva C. Screening of biofilm formation by beneficial vaginal lactobacilli and influence of culture media components. J Appl Microbiol. 2012; 113(6):1517-29.

2. Lavryk HS, Korniychuk OP. Antimicrobial properties of Lactobacilli against Staphylococci isolated from biofilms of patients with Acne vulgaris. Mikrobiologiâ ì biotehnologîa. 2020; 1(48):69-78.

3. Costerton $J W$. Structure and plasticity at various organization levels in the bacterial cell. Can J Microbiol. 1988;34(4):513-21.

4. Costerton JW, Geesey GG, Cheng KJ. How bacteria stick. Sci Am. 1978;238(1): 86-95.

5. Bryers JD. Bacterial biofilms. Curr Opin Biotechnol. 1993;4(2):197-204.

6. Toyofuku M, Inaba T, Kiyokawa T, Obana N, Yawata Y, Nomura N. Environmental factors that shape biofilm formation. Biosci Biotechnol Biochem. 2016;80(1):7-12.

7. Dufour D, Leung V, Lévesque CM. Bacterial biofilm: structure, function, and antimicrobial resistance. Endod Topics. 2010;22(1):2-16.

8. Momeni $B$. Division of labor: How microbes split their responsibility. Curr Biol. 2018;28(12):R697-9.

9. Alhede M, Lorenz M, Fritz BG, Jensen PØ, Ring HC, Bay L, Bjarnsholt T. Bacterial aggregate size determines phagocytosis efficiency of polymorphonuclear leukocytes. Med Microbiol Immunol. 2020; 209(6):669-680.

10. González JF, Hahn MM, Gunn JS. Chronic biofilmbased infections: skewing of the immune response. Pathog Dis. 2018;76(3):fty023. 
11. Deschaine BM, Heysel AR, Lenhart BA, Murphy $H A$. Biofilm formation and toxin production provide a fitness advantage in mixed colonies of environmental yeast isolates. Ecol Evol. 2018; 8(11):55415550.

12. McDonough KA, Rodriguez A. The myriad roles of cyclic AMP in microbial pathogens: from signal to sword. Nat Rev Microbiol. 2011; 10(1):27-38.

13. Shan Y, Brown Gandt A, Rowe SE, Deisinger JP, Conlon BP, Lewis K. ATP-dependent persister formation in Escherichia coli. MBio. 2017; 8(1): e02267-16.

14. Singh PK, Schaefer AL, Parsek MR, Monin-ger TO, Welsh MJ, Greenberg EP. Quorum-sensing signals indicate that cystic fibrosis lungs are infected with bacterial biofilms. Nature. 2000; 407(6805):762764.

15. Reigada I, Pérez-Tanoira R, Patel JZ, Savijoki K, Yli-Kauhaluoma J, Kinnari TJ, Fallarero A. Strategies to Prevent Biofilm Infections on Biomaterials: Effect of Novel Naturally-Derived Biofilm Inhibitors on a Competitive Colonization Model of Titanium by Staphylococcus aureus and SaOS-2 Cells. Microorganisms. 2020;8(3):345.

16. Singh S, Singh SK, Chowdhury I, Singh R. Understanding the Mechanism of Bacterial Biofilms Resistance to Antimicrobial Agents. Open Microbiol J. 2017; 11:53-62.

17. Lewis $K$. Persister cells, dormancy and infectious disease. Nat Rev Microbiol. 2007; 5(1):48-56.

18. Gefen O, Chekol B, Strahilevitz J, Balaban NQ. TDtest: easy detection of bacterial tolerance and persistence in clinical isolates by a modified diskdiffusion assay. Sci Rep. 2017; 7:41284.

19. Moormeier DE, Bayles KW. Staphylococcus aureus biofilm: a complex developmental organism. Mol Microbiol. 2017; 104(3):365-376.

20. Kong C, Chee CF, Richter K, Thomas N, Abd Rahman $N$, Nathan $S$. Suppression of Staphylococcus aureus biofilm formation and virulence by a benzimidazole derivative, UM-C162. Sci Rep. 2018; 8(1):2758.

21. Ramos-Vivas J, Chapartegui-González I, Fernández-Martínez M, González-Rico C, Fortún J, Escudero R, Marco F, Linares L, Montejo M, Aranza- mendi M, Muñoz P, Valerio M, Aguado JM, Resino E, Ahufinger IG, Vega AP, Martínez-Martínez L, Fariñas $M C$. Biofilm formation by multidrug resistant Enterobacteriaceae strains isolated from solid organ transplant recipients. Sci Rep. 2019; 9(1):8928.

22. Lajhar SA, Brownlie J, Barlow R. Characterization of biofilm-forming capacity and resistance to sanitizers of a range of E. coli O26 pathotypes from clinical cases and cattle in Australia. BMC Microbiol. 2018; 18(1):41.

23. Kamali E, Jamali A, Ardebili A, Ezadi F, Mohebbi A. Evaluation of antimicrobial resistance, biofilm forming potential, and the presence of biofilm-related genes among clinical isolates of Pseudomonas aeruginosa. BMC Res Notes. 2020; 13(1):27.

24. Zhong $X$, Wu Q, Zhang J, Ma Z, Wang J, Nie X, Ding $Y$, Xue L, Chen $M$, Wu S, Wei X, Zhang $Y$. Campylobacter jejuni in Biofilm Formation Under Aerobic Conditions and Inhibition by $\mathrm{ZnO}$ Nanoparticles. Front Microbiol. 2020; 11:207.

25. Ramage $G$, Rajendran $R$, Sherry L, Williams $C$. Fungal biofilm resistance. Int J Microbiol. 2012; 2012:528521.

26. Keshvardoust P, Huron VAA, Clemson M, Constancias $F$, Barraud N, Rice $S A$. Biofilm formation inhibition and dispersal of multi-species communities containing ammonia-oxidising bacteria. NPJ Biofilms Microbiomes. 2019; 5(1):22.

27. Aldrich AL, Heim CE, Shi W, Fallet RW, Duan B, Kielian T. TLR2 and caspase-1 signaling are critical for bacterial containment but not clearance during craniotomy-associated biofilm infection. $J$ Neuroinflammation. 2020; 17(1):114.

28. Hänsch GM. Host defence against bacterial biofilms: "Mission Impossible"? Int Sch Res Notices. 2012; 2012:1-17.

29. Babbar A, Barrantes I, Pieper DH, Itzek A. Superantigen SpeA attenuates the biofilm forming capacity of Streptococcus pyogenes. J Microbiol. 2019; 57(7):626-636.

30. Mishra R, Panda AK, De Mandal S, Shakeel M, Bisht SS, Khan J. Natural Anti-biofilm Agents: Strategies to Control Biofilm-Forming Pathogens. Front Microbiol. 2020; 11:566325. 
31. Toyofuku M, Inaba T, Kiyokawa T, Obana N, Yawata Y, Nomura N. Environmental factors that shape biofilm formation. Biosci Biotechnol Biochem. 2016; 80(1):7-12.

32. Lawrence JR, Korber DR, Hoyle BD, Costerton JW, Caldwell DE. Optical sectioning of microbial biofilms. J Bacteriol. 1991; 173(20):6558-6567.

33. Korber DR, Wolfaardt GM, Brözel V, MacDonald R, Niepel T. Reporter systems for microscopic analysis of microbial biofilms. Methods Enzymol. 1999; 310:3-20.

34. Kim J, Park HD, Chung S. Microfluidic approaches to bacterial biofilm formation. Molecules. 2012; 17(8):9818-9834.

35. Roy R, Tiwari M, Donelli G, Tiwari $V$. Strategies for combating bacterial biofilms: A focus on anti-biofilm agents and their mechanisms of action. Virulence. 2018; 9(1):522-554.

36. Coenye T, Nelis HJ. In vitro and in vivo model systems to study microbial biofilm formation. $\mathrm{J} \mathrm{Mi-}$ crobiol Methods. 2010; 83(2):89-105.

37. Kadurugamuwa JL, Sin L, Albert E, Yu J, Francis K, DeBoer $M$, Rubin $M$, Bellinger-Kawahara $C$, Parr TR Jr, Contag PR. Direct continuous method for monitoring biofilm infection in a mouse model. Infect Immun. 2003; 71(2):882-90.

38. Xiong YQ, Willard J, Kadurugamuwa JL, Yu J, Francis KP, Bayer AS. Real-time in vivo bioluminescent imaging for evaluating the efficacy of antibiotics in a rat Staphylococcus aureus endocarditis model. Antimicrob Agents Chemother. 2005; 49(1):380-387.

39. Roche ED, Renick PJ, Tetens SP, Ramsay SJ, Daniels $E Q$, Carson $D L$. Increasing the presence of biofilm and healing delay in a porcine model of MRSA-infected wounds. Wound Repair Regen. 2012; 20(4):537-543.

40. Donlan RM. Biofilms: Microbial life on surfaces. Emerg Infect Dis. 2002; 8(9):881-890.

41. Roy R, Tiwari M, Donelli G, Tiwari $V$. Strategies for combating bacterial biofilms: A focus on anti-biofilm agents and their mechanisms of action. Virulence. 2018; 9(1):522-554.

42. Hentzer M, Riedel K, Rasmussen TB, Heydorn A, Andersen JB, Parsek MR, Rice SA, Eberl L, Molin S,
Høiby N, Kjelleberg S, Givskov M. Inhibition of quorum sensing in Pseudomonas aeruginosa biofilm bacteria by a halogenated furanone compound. $\mathrm{Mi}$ crobiology. 2002; 148(1):87-102.

43. Shen Y, Köller T, Kreikemeyer B, Nelson DC. Rapid degradation of Streptococcus pyogenes biofilms by PlyC, a bacteriophage-encoded endolysin. $J A n$ timicrob Chemother. 2013; 68(8):1818-1824.

44. Kharidia R, Liang JF. The activity of a small lytic peptide PTP-7 on Staphylococcus aureus biofilms. $J$ Microbiol. 2011; 49(4):663-668.

45. Hsu ST, Breukink E, Tischenko E, Lutters MA, de Kruijff B, Kaptein R, Bonvin AM, van Nuland NA. The ni-sin-lipid II complex reveals a pyrophosphate cage that provides a blueprint for novel antibiotics. Nat Struct Mol Biol. 2004; 11(10):963-967.

46. Parisot J, Carey S, Breukink E, Chan WC, Narbad A, Bonev $B$. Molecular mechanism of target recognition by subtilin, a class I lanthionine antibiotic. Antimicrob Agents Chemother. 2008; 52(2):612-618.

47. Gagnon MG, Roy RN, Lomakin IB, Florin T, Mankin AS, Steitz TA. Structures of proline-rich peptides bound to the ribosome reveal a common mechanism of protein synthesis inhibition. Nucleic Acids Res. 2016; 44(5):2439-2450.

48. Segev-Zarko L, Saar-Dover R, Brumfeld V, Mangoni $M L$, Shai Y. Mechanisms of biofilm inhibition and degradation by antimicrobial peptides. Biochem J. 2015; 468(2):259-270.

49. Willcox MD, Hume EB, Aliwarga Y, Kumar N, Cole N. A novel cationic-peptide coating for the prevention of microbial colonization on contact lenses. J Appl Microbiol. 2008; 105(6):1817-1825.

50. Wu S, Liu G, Jin W, Xiu P, Sun C. Antibiofilm and Anti-Infection of a Marine Bacterial Exopolysaccharide Against Pseudomonas aeruginosa. Front Microbiol. 2016; 7:102.

51. Vane JR, Botting RM. Anti-inflammatory drugs and their mechanism of action. Inflamm Res. 1998; 47(2):78-87.

52. Sambanthamoorthy K, Luo C, Pattabiraman N, Feng $X$, Koestler B, Waters CM, Palys TJ. Identification of small molecules inhibiting diguanylate cyclases to control bacterial biofilm development. Biofouling. 2014; 30(1):17-28. 
53. Engelsöy U, Rangel I, Demirel I. Impact of Proinflammatory Cytokines on the Virulence of Uropathogenic Escherichia coli. Front Microbiol. 2019;10:1051.

54. Doster RS, Kirk LA, Tetz LM, Rogers LM, Aronoff DM, Gaddy JA. Staphylococcus aureus Infection of Human Gestational Membranes Induces Bacterial Biofilm Formation and Host Production of Cytokines. J Infect Dis. 2017; 215(4):653-657.

55. Yimer EM, Mohammed OA, Mohammedseid SI. Pharmacological exploitation of nonsteroidal antiinflammatory drugs as potential sources of novel antibacterial agents. Anti-Infect. Agents. 2019; 17(2):81-92.

56. Laudy AE, Mrowka A, Krajewska J, Tyski S. The Influence of Efflux Pump Inhibitors on the Acti-vity of Non-Antibiotic NSAIDS against Gram-Negative Rods. PloS One. 2016; 11(1):e0147131.

57. Mohsen A, Gomaa A, Mohamed F, Ragab R, Mennatallah E, Al-Hussein A, Khalaf A, Kamal M, Mokhtar S, Hadeer M, Salah I, Abbas R, Sameh Abd El-Baky RM. Antibacterial, Anti-biofilm Activity of Some Nonsteroidal Anti-Inflammatory Drugs and $\mathrm{N}$-acetyl Cysteine against Some Biofilm Producing Uropathogens. Am J Epidemiol Infect Dis. 2015; 3(1):1-9.

58. Bhardwaj RG, Ellepolla A, Drobiova H, Karched M. Biofilm growth and IL- $8 \&$ TNF- $\alpha$-inducing properties of Candida albicans in the presence of oral gram-positive and gram-negative bacteria. $B M C$ Microbiol. 2020; 20(1):156.

59. Roux D, Gaudry S, Khoy-Ear L, Aloulou M, PhillipsHoulbracq M, Bex J, Skurnik D, Denamur E, Monteiro $R C$, Dreyfuss D, Ricard JD. Airway fungal colonization compromises the immune system allowing bacterial pneumonia to prevail. Crit Care Med. 2013; 41(9):e191-199.

60. Krause J, Geginat G, Tammer I. Prostaglandin E2 from Candida albicans Stimulates the Growth of Staphylococcus aureus in Mixed Biofilms. PLoS One. 2015; 10(8): $\mathrm{e} 0135404$.

61. Alem MA, Douglas LJ. Effects of aspirin and other nonsteroidal anti-inflammatory drugs on biofilms and planktonic cells of Candida albicans. Antimicrob Agents Chemother. 2004; 48(1):41-47.

62. de Matos RF, Mendonça LCV, da Silva Souza KG, Fonseca AAD, Costa EMS, de Lima MVD, Vieira $J M D S$, de Brito MTFM, Monteiro MC. Nimesulide inhibits pathogenic fungi: PGE2-dependent mechanisms. Folia Microbiol. 2017; 62(2):169174.

63. Ahmed EF, El-Baky RMA, Ahmed ABF, Waly NG, Gad GFM. Antibacterial Activity of Some Nonsteroidal An-ti-inflammatory Drugs against Bacteria Causing Urinary Tract Infection. Am J Infect Dis Microbiol. 2017; 5(1):66-73.

64. Chen S, Chen Y, Feng Z, Chen X, Wang Z, Zhu J, Jin J, Yao Q, Xiang L, Yao L, Sun J, Zhao L, Fung H, Laiyi Wong E, Dong D. Barriers of effective health insurance coverage for rural-to-urban migrant workers in China: a systematic review and policy gap analysis. BMC Public Health. 2020; 20(1):408.

\section{Мікробні біоплівки та деякі аспекти використання протизапальних препаратів}

Т. М. Руминська, А. Р. Гураль, Ю. Т. Конечний, Р. Б. Винницька, А. В. Лозинський, Ю. Т. Салига, О. П. Корнійчук, Р. Б. Лесик

В огляді наведено літературні дані щодо впливу нестероїдних протизапальних препаратів на утворення бактеріальних біоплівок. Показано роль біоплівкових структур як фактору вірулентності мікроорганізмів та охарактеризовано захисні реакції макроорганізму при інфекційних процесах спричиненими бактеріями продуцентами біоплівок. Також в статті наведені приклади методів вивчення плівкоутворення та стратегії управління цим процесом. Показана перспективність подальшого вивчення складної взаємодії між бактеріальними патогенами у складі біоплівок, що може допомогти у розробці подальших терапевтичних стратегій проти плівкозалежних інфекцій.

К л юч о в і с с о в а: нестероїдні протизапальні препарати, мікробіота, дисбактеріоз, простаноїди, циклооксигеназа, біоплівки 


\section{Микробные биопленки и некоторые аспекты использования противовоспалительных препаратов}

Т. М. Румынская, А. Р. Гураль, Ю. Т. Конечный, Р. Б. Винницкая, А. В. Лозинский, Ю. Т. Салыга, А. П. Корнийчук, Р. Б. Лесык

В обзоре приведены литературные данные о влиянии нестероидных противовоспалительных препаратов на образование бактериальных биопленок. Показана роль биоплёночных структур как фактора вирулентности микроорганизмов и охарактеризованы защитные реакции макроорганизма при инфекционных процессах вызванными бактериями — продуцента- ми биопленок. Также в статье приведены примеры методов изучения пленкообразования и стратегии управления этим процессом. Показана перспективность дальнейшего изучения сложного взаимодействия между бактериальными патогенами в составе биопленок, что может помочь в разработке дальнейших терапевтических стратегий против пленко-зависимых инфекций.

Кл юч е в ы е сл ов а: нестероидные противовоспалительные препараты, микробиота, дисбактериоз, простаноиды, циклооксигеназа, биопленки.

Received 30.05.2021 